Review of Social Economy

\title{
Social cooperatives, social welfare associations and social networks
}

\section{Giacomo Degli Antoni \& Fabio Sabatini}

To cite this article: Giacomo Degli Antoni \& Fabio Sabatini (2016): Social cooperatives, social welfare associations and social networks, Review of Social Economy, DOI: 10.1080/00346764.2016.1226510

To link to this article: http://dx.doi.org/10.1080/00346764.2016.1226510

册 Published online: 12 Sep 2016.

Submit your article to this journal $[\pi$

Џلll Article views: 128

Q View related articles $₫$

View Crossmark data $\asymp$ 


\title{
Social cooperatives, social welfare associations and social networks
}

\author{
Giacomo Degli Antoni ${ }^{\mathrm{a}, \mathrm{d}}$ and Fabio Sabatini ${ }^{\mathrm{b}, \mathrm{c}}$
}

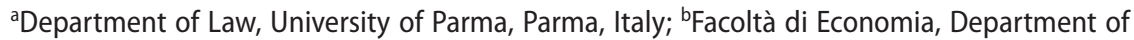
Economics and Law, Sapienza University of Rome, Roma, Italy; ' Laboratory for Comparative Social Research (LCSR), National Research University Higher School of Economics, Moscow, Russia; ${ }^{d}$ EconomEtica (Inter-University Center for Economic Ethics and Corporate Social Responsibility), Milano, Italy

\begin{abstract}
We use an original data-set to study how participation in two types of non-profit organizations - i.e. social welfare associations and social cooperatives - affects individual social capital, understood as a network of cooperative relationships. Participation in both the types of organization allows members to start new social relations. However, social welfare associations seem to play a significantly greater role in the development of volunteers' social capital, favouring the creation of weak ties that are used to exchange information and advice, and offering the opportunity to establish stronger ties entailing concrete mutual support. Within social cooperatives, workers appear to develop their individual social capital to a greater extent than volunteers. Our results suggest that the composition of the workforce, the depth of members' involvement in the organization's activities and the human resources strategies adopted by the management influence the creation of cooperative relations through on-the-job interactions.
\end{abstract}

ARTICLE HISTORY Received 7 November 2015; Accepted 5 August 2016

KEYWORDS Social capital; non-profit organizations; social networks; social cooperatives; volunteering

JEL CODES L31; L33; P13; Z1; Z13

\section{Introduction}

The early literature on social capital commonly claimed that non-profit organizations play a positive role in the diffusion of civic attitudes, sentiments of trust and the development of networks of cooperative relationships. After the publication of the seminal work by Putnam et al. (1993), many empirical studies have measured social capital through indicators of membership of non-profit, non-governmental, associations belonging to civil society. The habit of considering civil society as an integral part of social capital has since then spread 
among scholars and policy-makers, causing some confusion between the two concepts (see e.g. the influential World Bank's guidelines for social development: World Bank 2011). An implication of this approach is that support for the nonprofit sector and for participatory processes has long been considered a decisive policy tool for the accumulation of social capital, the promotion of welfare and the strengthening of democracy (European Commission 2005; Grootaert and Van Bastelaer 2001; OECD 2010).

We argue that non-profit organizations are not all alike in how they contribute to the creation of social capital. Different types of organizations play different roles depending, for example, on their institutional aims and purposes, the composition of the workforce and the effort made by the organization to promote social interactions among its members. To investigate this thesis, we study how participation in two specific types of non-profit organizations - social welfare associations (hereafter SWAs) and social cooperatives (SCs) - is related to the development of social networks of cooperative relationships among their workers and volunteers.

With respect to the previous studies in the field (see Section 2), our work innovates in two ways. First, it focuses on social networks, by studying the effect of participation in different types of organizations on the development of cooperative relations. Networks are analysed through the elaboration of indicators of the strength of relationships. We measure the weak ties allowing the transmission of information and advice, and the stronger ties entailing concrete mutual support. The indicators that we use as outcome variables allow us to assess how involvement in SWAs and SCs affects aspects of social capital, such as networks of relations, which have not been investigated before and primarily exert their effects at the micro-level at both the individual (e.g. Antoci et al. 2012; Brown et al. 2006; Fiorillo and Sabatini 2011; Folland 2006) and the organizational level (Hansen 1999; Leana and Van Buren 1999). Second, unlike previous studies on the effect of membership in non-profit organizations, which focused solely on volunteers, our sample enables us to analyse the effect of participation on two distinct types of subjects, i.e. volunteers and workers. In fact, we will consider a distinctive feature of SWAs and SCs in our sample, i.e. the composition of the organization's workforce. ${ }^{1}$

We specifically focus on those organizations that, in our view, better match Putnam's concept of civic community because they share the institutional aim of pursuing solidarity goals, (Putnam 2000; Putnam et al. 1993). The strategy of distinguishing between organizations of a different nature and with different characteristics but similar purposes enhances understanding of the relationship between the non-profit sector and social capital, by suggesting how non-profit

\footnotetext{
1'In 1991, Law 266 (in Italy) established that, in order to access public grants and to benefit from tax relief, organizations must have solidarity aims and their members must be for the most part volunteers. All the SWAs included in our sample conformed to Law 266/1991. In SCs, by contrast, volunteers represented a residual part of the workforce.
} 
organizations may be modelled for the purpose of fostering the accumulation of social capital. The effect of SCs - and, more generally, of cooperative firms on the structural components of individual social capital has to date been unexplored, despite the growing attention that has been paid to this type of enterprise in the economics literature. Our study also makes a first step towards filling this gap.

Our research question can be summarized as follows: may different types of non-profit organizations, with similar purposes but diverse natures and characteristics, produce different effects on the creation of social networks by their members?

To reach our goals, we draw on a unique data-set of individual-level microdata collected by the authors through the administration of a questionnaire to a sample of volunteers and workers in SCs and SWAs in the Italian province of Parma.

Creating social capital across employees is often considered to be an important goal by organizations. Case studies show that the building of a cooperative climate within the workforce and favouring the establishment of trust relations among employees and between employees and managers generally constitute key tasks for management. Studies on life satisfaction, on the other hand, show that workers' well-being is significantly affected by the quality of relationships with colleagues, the establishment of friendships in the workplace and other non-economic dimensions of job quality (Findlay et al. 2013). According to Gui (2000), these 'relational assets' contribute to firms' economic performance just as do new investments in physical capital, because they increase workers' effort and productivity, thereby improving the organization's performance (Andrews 2010; Zhang and Lin 2016). The possible linkage between the workforce's social capital and labour productivity may develop along two dimensions. Firstly, social capital fosters the diffusion of knowledge and information among workers (e.g. Mäkelä and Brewster 2009; Nahapiet and Ghoshal 1998),'making possible the achievement of certain ends that would not be attainable in its absence' (Coleman 1990: 302). Secondly, social interactions may affect workers' effort and motivation. In their famous study on organizations, March and Simon (1958) argued that, even if managers are authoritative and the enterprise's hierarchy is definite and well functioning, employees are able to influence the achievement of tasks in different ways, such as by delaying the execution of orders and, more in general, engaging in opportunistic behaviour. Many studies show that, if human relations within the workforce are trustful and relaxed, employees are more inclined to do their best at work, and they will be more likely to sanction shirking behaviour through peer monitoring (Huck et al. 2012; Kandel and Lazear 1992; Sabatini 2008). More in general, the establishment of trust-intensive relationships across the workforce favours organizational socialization, meaning 'the process by which new members acquire the attitudes, values, knowledge and expected behaviour needed to participate as organizational members' (HaskiLeventhal and Bargal 2008: 68). In its turn, socialization strengthens employee 
commitment in terms of attachment to the organization, identification with its goals and willingness to work hard for it (Haski-Leventhal and Bargal 2008).

The experience of the non-profit organizations investigated in this study shows that the composition of the workforce, the depth of members' involvement in the organization's activities - in particular in terms of current motivation to perform their work within the organization - and human resources strategies adopted by the management influence the creation of cooperative relations through on-the-job interactions.

The next sections briefly provide some definitions and review the related literature. Then we describe our data and empirical strategy. The following sections present some descriptive evidence and the econometric analysis. A discussion and interpretation of the results are offered in the last sections.

\section{Definitions and related literature}

An SWA is a type of non-profit organization that has the statutory objective of carrying out charitable activities such as the provision of social welfare services for disadvantaged or deprived people, or the promotion of collective actions on public interest issues such as civil rights and environmental protection. Italian SCs conjugate characteristics of traditional cooperative enterprises and traditional non-profit organizations in which ownership and governance rights are assigned to the workers or to a mix of categories of stakeholders (Degli Antoni and Portale 2011). Residual earnings are for the most part reinvested in reserves that are not available to members. In this perspective, SCs can be considered non-profit organizations with a distribution constraint (Borzaga and Tortia 2006). Both these types of organization are widespread across the world. For example, World Values Survey data include information about membership in all the possible types of SWA, i.e. those engaged in activities of assistance, health care, environmental protection, childcare or elderly care, education and civil rights protection. SCs, which almost doubled in number in Italy between 2001 and 2011 , reaching a total of 11,264 and employing about 320,513 workers, ${ }^{2}$ may be included in the broader category of social enterprises ${ }^{3}$ (Borzaga and Defourny 2001; Kerlin 2006), whose presence has grown dramatically in many regions of the world over the past two decades (Kerlin 2010).

Social capital is generally referred to as all 'features of social life - networks, norms, and trust - that enable participants to act together more effectively to pursue shared objectives' (Putnam 1995: 67). At the level of individuals, Bourdieu (1980) stressed the role of social relations and defined social capital as 'the sum

\footnotetext{
${ }^{2} 9^{\circ}$ 'Censimento industria e servizi e Istituzioni non profit 2011' (Census of industry and services and nonprofit institutions in 2011), http://dati-censimentoindustriaeservizi.istat.it/.

${ }^{3}$ The category 'social enterprise' presents some differences between the US and the European context. In the latter, SCs are explicitly considered as social enterprises (see in particular the approach developed by EMES: European Research Network; see also Kerlin 2006).
} 
of the resources, actual or virtual, that accrue to an individual or group by virtue of possessing a durable network of relationships of mutual acquaintance and recognition' (Bourdieu and Wacquant 1992). Putnam (1995) argued that a research priority is to clarify the dimensions of social capital. Uphoff (1999) drew a distinction between the structural and cognitive dimensions of the concept. Structural social capital concerns individuals' behaviours and mainly takes the form of networks. Cognitive social capital derives from individuals' perceptions resulting in norms, values and beliefs that contribute to cooperation. ${ }^{4}$

Several studies have previously investigated the effect of associational participation on social capital's cognitive dimensions. At the individual level, Stolle and Rochon (1998) used World Values Survey cross-sectional data from the US, Germany and Sweden to show that membership of diverse associations affects social capital in different ways. The authors found that the degree of 'associational diversity' is positively correlated with generalized trust and community reciprocity among members (61). Sabatini et al. (2014) showed that workers of traditional cooperative enterprises tend to develop more generalized trust than workers employed in other kinds of organization (public or for-profit) due to the specific characteristics of the work environment in cooperatives. At the macrolevel, Knack and Keefer (1997) investigated the effect of different types of organizations on generalized trust. More recently, Grießhaber and Geys (2012) found that the impact of membership on corruption significantly varies according to the association's characteristics in terms of inclusiveness and interconnectedness in a cross-section of 20 European democracies. Similar results on the different effects of diverse types of association have been obtained by other authors (e.g. Hooghe 1998).

In this paper, we focus on the so far neglected structural dimension of social capital. We study how different types of organizations may affect the social networks of their members.

\section{Data-set, social capital indices and independent variables}

\subsection{Data-set}

The empirical analysis is based on an original data-set obtained by merging data collected by the authors through the administration of an anonymous questionnaire in two different surveys, in 2007 and 2011, respectively. Despite the economic crisis that occurred between the two years, the merging of the two data-sets seems not to undermine our empirical results. In fact, a dummy equal to 1 for subjects who filled in the questionnaire in 2007 and 0 for those who filled in the questionnaire in 2011 is not significantly related to the formation of social networks.

${ }^{4}$ On social capital dimensions see also Paldam (2000), Robison et al. (2002), and Schuller (2007). 
Table 1. Number of subjects by employment status (volunteers vs. workers) and type of organization.

\begin{tabular}{lcc}
\hline & Volunteers & Workers \\
\hline Social welfare associations & 290 & 0 \\
Social cooperatives & 32 & 106 \\
\hline
\end{tabular}

In 2007, respondents were volunteers in SWAs. Two hundred and ninety members of 45 associations operating in the province of Parma in northern Italy participated in the survey. The number of volunteers per association was 6.4 on average (minimum 2, maximum 11 and standard deviation 2.4). The sample of organizations was a stratified random sample ${ }^{5}$ representing $10 \%$ of organizations in the province. Volunteers were randomly chosen among members of the associations. They filled in a questionnaire of 64 questions about their experience as volunteers and returned it immediately to the person in charge of administering and collecting the questionnaires. We did not observe self-selection problems with respect to volunteers of SWAs because volunteers were randomly selected and they all returned their questionnaire.

In 2011, the questionnaire was administered to volunteers and salaried workers at SCs operating in the same province. SCs were contacted through a consortium of associations involving $37 \mathrm{SCs}$. This consortium represents a significant part of the $73 \mathrm{SCs}$ operating in the province. All $37 \mathrm{SCs}$ were invited to take part in the research project. Seventeen SCs agreed to participate (12 of which were A-type, 1 was B-type and 4 were A+B-type). ${ }^{6}$ In total, we collected questionnaires from 32 volunteers in 12 SCs (2.7 volunteers per organization on average, minimum 1 , maximum 5 and standard deviation 1.5$)^{7}$ and 106 workers in 17 SCs (6.2 workers per organization on average, minimum 1, maximum 15 and standard deviation 4.5). In the 2011 survey, we asked managers of SCs to distribute questionnaires to all their workers and volunteers. Questionnaires were distributed and filled in at home. Since many subjects did not return the questionnaires (we received questionnaires from $26 \%$ of workers and $9 \%$ of volunteers), ${ }^{8}$ there may have been a problem of self-selection with respect to subjects involved in $\mathrm{SC}$. However, our main empirical result (i.e. that volunteers seem to be less able to develop networks when they operate in SCs rather than

\footnotetext{
${ }^{5}$ Strata referred to the district where the association operated (the province of Parma is divided into four administrative districts, very different in terms of population density) and its main activity.

${ }^{6}$ Type $A^{\prime}$ cooperatives are those that aim to supply welfare services such as healthcare, assistance, education and environment protection services. 'Type $B^{\prime}$ cooperatives are those promoting work integration for disadvantaged people. 'Type A+B' cooperatives are those pursuing both aims (see Law 381/1991 - Disciplina delle cooperative sociali, available at the url: bit.ly/381-1991 - in Italian).

${ }^{7}$ The sample of volunteers in SCs was smaller than the samples of workers in SCs and volunteers in SWAs. This reflects the limited involvement of volunteers in SCs. Twelve of the 17 SCs included in our sample had fewer than 10 volunteers and 14 had fewer than 20. Five SCs did not return any questionnaires filled in by volunteers.

${ }^{8}$ With respect to SCs, the lower percentage of volunteers involved in the research is mainly due to the greater difficulty of contacting them with respect to workers (who spend much more time within the organization).
} 
in SWAs) induces us to think that self-selection does not invalidate our result. What we found is that the 'more cooperative' individuals (more inclined to fill in and return the questionnaires) among volunteers of SCs developed less social capital than volunteers of SWAs. If self-selection was at work, we should expect that, without it, our results would be even stronger.

In both the surveys, we asked senior members with detailed knowledge of their organization questions about the organization's characteristics, such as its size, operational characteristics, etc.

Table 1 summarizes the size of the sub-samples of volunteers and workers across the two types of organization.

Our data are not representative at a national level. They reflect a situation observed in a province of Italy with 445,283 inhabitants characterized by many SWAs and a significant number of SCs. ${ }^{9}$ However, the SWAs and the SCs considered in our analysis conform to Laws 266/1991 (see footnote 1) and 381/1991 (see footnote 6), respectively. As such, they are in general comparable to the associations and cooperatives operating in Italy and conforming to the previous Laws.

The questionnaire was specifically designed by the authors to investigate the relationship between participation in different kinds of organizations and the creation of social capital. This special focus allowed us to carry out an analysis that would have not been possible using existing national databases.

\subsection{Social capital indices}

Following the approach of Degli Antoni (2009), who drew on a subset of our data to analyse associations only, we elaborated two indices of social capital intended as networks of cooperative relations. They explicitly considered the degree of attachment characterizing the relations formed through the organization. A proxy named Strong_ties was the mean value of the standardized ${ }^{10}$ answers to the following questions:

(1) How many of the people that you have met through the association/ cooperative would you:

(a) Talk to about family problems?

(b) Trust to look after your relatives (e.g. children or elderly persons)?

(c) Ask to take care of your home when you are on holiday?

(d) Give/ask for help with errands such as shopping, accompanying children or elderly persons to do different activities, etc.?

\footnotetext{
${ }^{9}$ With 7.3 voluntary associations per 10,000 inhabitants, Parma has the ninth largest number of voluntary associations per inhabitant (Istat 2003) among the 113 Italian provinces. It has the 37th largest number, with 17.08 per 100,000 inhabitants, of SCs (our calculation on data from Istat: http://dati-censimentoindustriaeservizi.istat.it/ and http://demo.istat.it/bil20111009/index04.html).

${ }^{10}$ The standardization procedure is: $\frac{x_{i c}-\min \left(x_{i}\right)}{\max \left(x_{i}\right)-\min \left(x_{i}\right)}$ where: $x_{i c}$ is the value $i$ related to the organization $c$. This standardization process creates standardized indicators with values ranging between 0 and 1 , and generates a more robust trial in the presence of outliers, which seem to characterize our indicators.
} 
The second index of social capital, named Weak_ties, was the mean value of the standardized answers to the question:

(2) With how many of the people that you have met through the association/cooperative have you started the following relations:

(a) Phone calls to ask for information or advice?

(b) Doing not very demanding errands?

(c) Asking for information about job opportunities?

In adopting the labels 'strong ties' and 'weak ties' to denote these indicators, we basically follow Granovetter's (1973) notion of the strength of ties as a'combination of the amount of time, the emotional intensity, the intimacy (mutual confiding), and the reciprocal services which characterize the tie' (1973: 1361). According to this definition, the act of providing concrete mutual support reflects a high 'degree of strength' of an interpersonal tie. However, we are aware that ties entailing lighter forms of support - such as the provision of information or advice on the telephone - may in principle match Granovetter's (1973) definition of strong ties as well. The label 'weak' that we apply to the indicator serves only to compare these ties with the stronger relations entailing more concrete forms of support.

\subsection{Independent variables}

The two independent variables of main interest were:

- A dummy variable (Volunteer_in_association) equal to 1 if the respondent was a volunteer in a SWA (the dummy took the value of 0 if the respondent was a volunteer or a worker in a SC).

- A dummy variable (Worker) equal to 1 if the respondent was a worker in a SC (it was equal to 0 if the respondent was a volunteer, either in a SC or in a SWA).

We included in our regressions several control variables that enabled us to interpret our results in light of some characteristics of the organizations and of the associational activities carried out by their members.

At the individual level, the independent variables included in the regressions concerned socio-demographic characteristics, and the depth and type of respondents' involvement in the organization. At the level of the organization, the independent variables included in the regressions concerned various operational and structural characteristics of the organization. See Appendix 1 for a detailed description of these variables.

\section{Descriptive findings}

The descriptive statistics show that the majority of respondents developed new social relations through their participation in the organizations. The percentage 


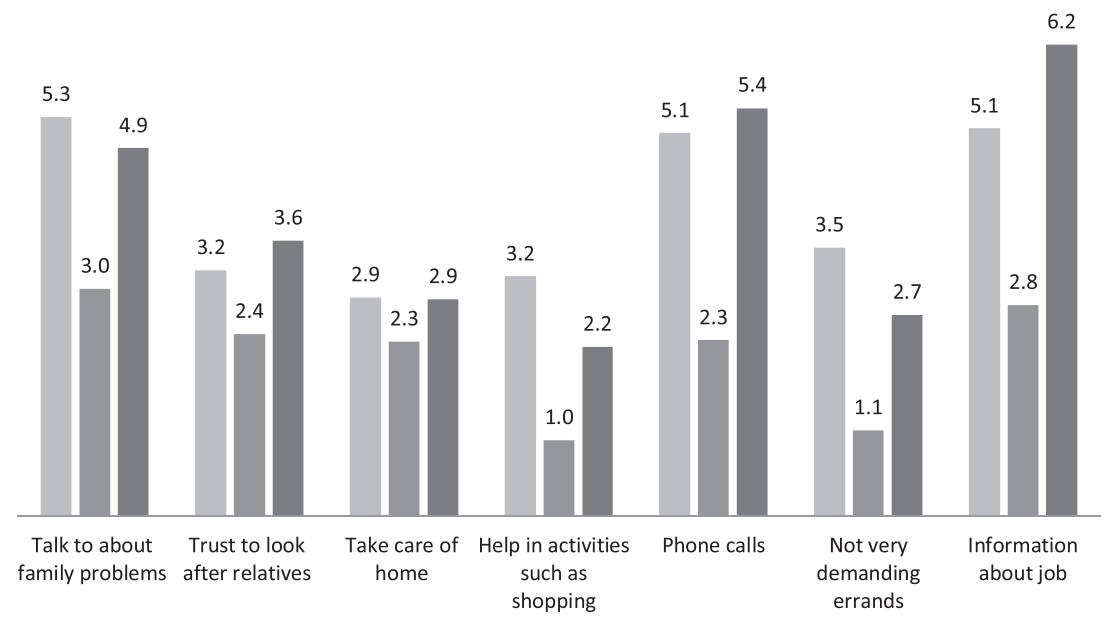

Figure 1. Trust-based relationships started between members and the people met through the organization (mean value on top of the bars).

of subjects who declared that they had started, with at least one person met through the organization, the relationships considered in the elaboration of the two social capital indices varies between $77.62 \%$ concerning the relation with people with whom one would talk to about family problems and $47.45 \%$ related to the relationship with people one would give/ask for help with errands such as shopping, accompanying a child or elderly persons in different circumstances, etc. On average, both volunteers of SWAs and workers of SCs started more relationships than volunteers of SCs, while no clear pattern emerges when the former two categories are compared (Figure 1).

When we consider the distribution of values concerning both the two social capital indices and the single indicators used in their elaboration (Table 2), we find that only in four cases does a statistically significant difference emerge between workers and volunteers across and within organization types. ${ }^{11}$ In the next section, we report a multivariate analysis conducted to investigate the possible differences characterizing the development of social capital by volunteer of SWAs and workers and volunteers of SCs through their involvement in the organization.

\footnotetext{
${ }^{11}$ The distribution of the Weak_ties variable has significantly greater values for volunteers in SWAs than for volunteers in SCs, the distributions of answers related to the creation of relations concerning phone calls to ask for information or advice and concerning help in doing not very demanding errands have significantly greater values for volunteers in SWAs than for volunteers in SCs, and the distribution of answers related to the creation of ties with subjects with whom one would talk to about family problems has significantly lower values for volunteers in SCs than for workers in SCs (Table 2).
} 
Table 2. Social capital creation comparing volunteers and workers within and between organization types.

\begin{tabular}{|c|c|c|c|}
\hline & $\begin{array}{c}\mathrm{H}_{0} \text { : volunteers of } \\
\text { SWAs }=\text { volunteers of SCs }\end{array}$ & $\begin{array}{c}\mathrm{H}_{0} \text { : volunteers of } \\
\text { SWAs }=\text { workers of SCs }\end{array}$ & $\begin{array}{c}\mathrm{H}_{0} \text { : volunteers of } \\
\mathrm{SCS}=\text { workers of SCs }\end{array}$ \\
\hline \multicolumn{4}{|c|}{ The two social capital indices } \\
\hline Strong ties index & $\begin{array}{r}-1.477 \\
(0.140)\end{array}$ & $\begin{array}{c}0.000 \\
(1.000)\end{array}$ & $\begin{array}{c}1.426 \\
(0.154)\end{array}$ \\
\hline Weak ties index & $\begin{array}{l}-1.960^{* *} \\
(0.050)\end{array}$ & $\begin{array}{r}-0.540 \\
(0.590)\end{array}$ & $\begin{array}{c}1.443 \\
(0.149)\end{array}$ \\
\hline \multicolumn{4}{|c|}{ Components of the strong ties index } \\
\hline $\begin{array}{l}\text { Talk to about family } \\
\text { problems }\end{array}$ & $\begin{array}{r}-1.345 \\
(0.179)\end{array}$ & $\begin{array}{l}0.762 \\
(0.466)\end{array}$ & $\begin{array}{l}1.747^{*} \\
(0.081)\end{array}$ \\
\hline $\begin{array}{l}\text { Trust to look after } \\
\text { relatives }\end{array}$ & $\begin{array}{c}0.297 \\
(0.766)\end{array}$ & $\begin{array}{l}1.320 \\
(0.187)\end{array}$ & $\begin{array}{c}0.480 \\
(0.632)\end{array}$ \\
\hline Take care of home & $\begin{array}{c}0.577 \\
(0.564)\end{array}$ & $\begin{array}{l}0.625 \\
(0.532)\end{array}$ & $\begin{array}{r}-0.240 \\
(0.811)\end{array}$ \\
\hline $\begin{array}{l}\text { Help in activities such } \\
\text { as shopping }\end{array}$ & $\begin{array}{l}-1.353 \\
(0.176)\end{array}$ & $\begin{array}{r}-1.359 \\
(0.174)\end{array}$ & $\begin{array}{c}0.532 \\
(0.595)\end{array}$ \\
\hline \multicolumn{4}{|c|}{ Components of the weak ties index } \\
\hline Phone calls & $\begin{array}{r}-1.755^{*} \\
(0.079)\end{array}$ & $\begin{array}{c}-0.812 \\
(0.417)\end{array}$ & $\begin{array}{c}1.121 \\
(0.262)\end{array}$ \\
\hline $\begin{array}{l}\text { Not very demanding } \\
\text { errands }\end{array}$ & $\begin{array}{r}-1.682^{*} \\
(0.093)\end{array}$ & $\begin{array}{r}-1.592 \\
(0.111)\end{array}$ & $\begin{array}{c}0.604 \\
(0.546)\end{array}$ \\
\hline Information about job & $\begin{array}{r}-0.139 \\
(0.890)\end{array}$ & $\begin{array}{c}1.389 \\
(0.165)\end{array}$ & $\begin{array}{c}0.880 \\
(0.379)\end{array}$ \\
\hline
\end{tabular}

Note: Wilcoxon rank-sum (Mann-Whitney) test - $p$-value in brackets.

*Significant at $10 \%$; ${ }^{* *}$ Significant at 5\%; ${ }^{* *}$ Significant at $1 \%$.

Table 3. Descriptive statistics of dependent and control variables.

\begin{tabular}{lccccc}
\hline & Observations & Mean & St. dev. & Min. & Max. \\
\hline $\begin{array}{l}\text { Dependent variables } \\
\text { Strong_ties }\end{array}$ & 377 & 0.042 & 0.072 & 0 & 1 \\
Weak_ties & 378 & 0.056 & 0.085 & 0 & 0.702 \\
Independent variables & & & & & \\
Volunteer_in_association & 428 & 0.678 & 0.468 & 0 & 1 \\
Worker & 428 & 0.248 & 0.432 & 0 & 1 \\
Age & 412 & 46.777 & 15.892 & 17 & 87 \\
Female & 421 & 0.563 & 0.497 & 0 & 1 \\
University & 422 & 0.280 & 0.449 & 0 & 1 \\
Time_in_org & 422 & 8.633 & 7.802 & 1 & 49 \\
Current_motivation & 435 & 5.680 & 1.141 & 1 & 7 \\
Entrance & 420 & 5.024 & 1.715 & 1 & 7 \\
Contact_volunteers & 410 & 3 & 1.363 & 1 & 5 \\
Years_org & 434 & 22.055 & 12.434 & 2 & 82 \\
Workers_volunteers & 439 & 47.813 & 74.411 & 3 & 354 \\
Formal_meetings & 427 & 3.646 & 5.124 & 0 & 25 \\
Informal_meetings & 429 & 0.918 & 0.274 & 0 & 1 \\
\hline
\end{tabular}

\section{Econometric results}

We used OLS estimates where standard errors were clustered by accounting for the organization to which the member belonged; that is, we assumed that observations were independent across groups, but not necessarily within 
Table 4. The effect of membership of different types of organization on individual social capital.

\begin{tabular}{|c|c|c|}
\hline \multirow[b]{3}{*}{ Regression } & 1 & 2 \\
\hline & \multicolumn{2}{|c|}{ Dependent variable } \\
\hline & Strong_ties & Weak_ties \\
\hline Volunteer_in_association & $\begin{array}{l}0.019 * * * \\
(0.006)\end{array}$ & $\begin{array}{l}0.030^{* * *} \\
(0.008)\end{array}$ \\
\hline Worker & $\begin{array}{l}0.018^{* * *} \\
(0.006)\end{array}$ & $\begin{array}{l}0.033^{* * *} \\
(0.008)\end{array}$ \\
\hline Age & $\begin{array}{c}0.000 \\
(0.000)\end{array}$ & $\begin{array}{c}0.000 \\
(0.000)\end{array}$ \\
\hline Female & $\begin{array}{c}-0.001 \\
(0.008)\end{array}$ & $\begin{array}{c}-0.012 \\
(0.009)\end{array}$ \\
\hline University & $\begin{array}{c}0.004 \\
(0.010)\end{array}$ & $\begin{array}{l}0.008 \\
(0.012)\end{array}$ \\
\hline Time_in_org & $\begin{array}{c}0.001 \\
(0.000)\end{array}$ & $\begin{array}{l}0.000 \\
(0.000)\end{array}$ \\
\hline Constant & $\begin{array}{c}0.016 \\
(0.015)\end{array}$ & $\begin{array}{l}0.032^{* *} \\
(0.015)\end{array}$ \\
\hline R-squared & 0.0084 & 0.0151 \\
\hline Root MSE & 0.0717 & 0.08197 \\
\hline Obs. & 364 & 366 \\
\hline $\begin{array}{l}\text { Wald test on equality of coefficients of } \\
\text { Volunteer_in_association and Worker }\end{array}$ & 0.927 & 0.757 \\
\hline
\end{tabular}

Note: Robust standard errors in brackets.

*Significant at $10 \%$; ${ }^{*}$ Significant at $5 \% ;{ }^{* *}$ Significant at $1 \%$.

groups, where the groups were formed by respondents belonging to the same organization.

Table 4 shows our regression results where the two indices of social capital were the dependent variables, in regressions 1 and 2, respectively. The main independent variables were the dummies Volunteer_in_association (equal to 1 if the respondent was a volunteer in a SWA) and Worker (equal to 1 if the respondent was a worker in a SC). The residual category consisted of volunteers in SCs. Therefore, the coefficients of Volunteer_in_association and Worker allow us to investigate the different effects on the dependent variable of being a volunteer in a SWA or a worker in a SC, respectively, instead of a volunteer in a SC. The effect on the dependent variables concerning the difference between being a volunteer in a SWA and a worker in a SC was analysed thorough Wald tests reported in the last line of the table.

Control variables were: age, gender, the number of years spent in the organization and a dummy variable equal to 1 if the respondent had at least a university degree. Note that all the results presented below do not significantly change if we consider, instead of this variable, a categorical variable measuring the level of education between 0 (no education) and 6 (postgraduate qualification). Descriptive statistics of all variables used in the estimates presented in this section (Tables 4 and 5 ) are reported in Table 3. 
Table 5. The effect of membership of different types of organization on individual social capital - robustness check.

\begin{tabular}{|c|c|c|c|c|}
\hline \multirow[b]{3}{*}{ Regression } & 1 & 2 & 3 & 4 \\
\hline & \multicolumn{4}{|c|}{ Dependent variable } \\
\hline & Strong_ties & Weak_ties & Strong_ties & Weak_ties \\
\hline $\begin{array}{l}\text { Volunteer_in_asso- } \\
\text { ciation }\end{array}$ & $\begin{array}{l}0.024^{* * *} \\
(0.008)\end{array}$ & $\begin{array}{l}0.036^{* * *} \\
(0.011)\end{array}$ & $\begin{array}{c}0.014 \\
(0.010)\end{array}$ & $\begin{array}{l}0.025^{* *} \\
(0.012)\end{array}$ \\
\hline Worker & $\begin{array}{l}0.030^{* * *} \\
(0.010)\end{array}$ & $\begin{array}{l}0.046^{* * *} \\
(0.011)\end{array}$ & $\begin{array}{l}0.024^{* *} \\
(0.009)\end{array}$ & $\begin{array}{l}0.039^{* * *} \\
(0.011)\end{array}$ \\
\hline Age & $\begin{array}{c}0.000 \\
(0.000)\end{array}$ & $\begin{array}{r}-0.000 \\
(0.000)\end{array}$ & $\begin{array}{c}0.000 \\
(0.000)\end{array}$ & $\begin{array}{c}-0.000 \\
(0.000)\end{array}$ \\
\hline Female & $\begin{array}{c}-0.003 \\
(0.008)\end{array}$ & $\begin{array}{r}-0.016^{*} \\
(0.009)\end{array}$ & $\begin{array}{c}0.000 \\
(0.009)\end{array}$ & $\begin{array}{c}-0.013 \\
(0.010)\end{array}$ \\
\hline University & $\begin{array}{c}0.007 \\
(0.009)\end{array}$ & $\begin{array}{c}0.012 \\
(0.011)\end{array}$ & $\begin{array}{c}0.006 \\
(0.009)\end{array}$ & $\begin{array}{c}0.011 \\
(0.011)\end{array}$ \\
\hline Time_in_org & $\begin{array}{l}0.001^{*} \\
(0.000)\end{array}$ & $\begin{array}{c}0.000 \\
(0.001)\end{array}$ & $\begin{array}{r}0.001^{*} \\
(0.000)\end{array}$ & $\begin{array}{c}0.000 \\
(0.001)\end{array}$ \\
\hline Years_org & $\begin{array}{c}-0.000 \\
(0.000)\end{array}$ & $\begin{array}{c}-0.000 \\
(0.000)\end{array}$ & $\begin{array}{c}-0.000 \\
(0.000)\end{array}$ & $\begin{array}{c}-0.000 \\
(0.000)\end{array}$ \\
\hline Workers_volunteers & $\begin{array}{c}0.000 \\
(0.000)\end{array}$ & $\begin{array}{c}0.000 \\
(0.000)\end{array}$ & $\begin{array}{c}0.000 \\
(0.000)\end{array}$ & $\begin{array}{c}0.000 \\
(0.000)\end{array}$ \\
\hline Informal_meetings & $\begin{array}{c}0.015^{*} \\
(0.009)\end{array}$ & $\begin{array}{c}0.018 \\
(0.015)\end{array}$ & $\begin{array}{c}0.007 \\
(0.010)\end{array}$ & $\begin{array}{c}0.010 \\
(0.013)\end{array}$ \\
\hline Formal_meetings & $\begin{array}{c}-0.001^{* *} \\
(0.001)\end{array}$ & $\begin{array}{c}-0.001^{* *} \\
(0.001)\end{array}$ & $\begin{array}{c}-0.001^{*} \\
(0.001)\end{array}$ & $\begin{array}{c}-0.001^{* *} \\
(0.001)\end{array}$ \\
\hline Entrance & $\begin{array}{c}0.006^{*} \\
(0.003)\end{array}$ & $\begin{array}{l}0.006^{* *} \\
(0.003)\end{array}$ & $\begin{array}{c}0.006^{*} \\
(0.003)\end{array}$ & $\begin{array}{c}0.005^{*} \\
(0.003)\end{array}$ \\
\hline Current_motivation & $\begin{array}{l}0.009^{* * *} \\
(0.003)\end{array}$ & $\begin{array}{l}0.011^{* * *} \\
(0.004)\end{array}$ & $\begin{array}{l}0.008^{* * *} \\
(0.003)\end{array}$ & $\begin{array}{l}0.009^{* *} \\
(0.004)\end{array}$ \\
\hline Contact_volunteers & & & $\begin{array}{r}0.008^{*} \\
(0.004)\end{array}$ & $\begin{array}{l}0.009^{* *} \\
(0.004)\end{array}$ \\
\hline Constant & $\begin{array}{r}-0.080 \\
(0.048)\end{array}$ & $\begin{array}{c}-0.071 \\
(0.043)\end{array}$ & $\begin{array}{c}-0.084^{*} \\
(0.049)\end{array}$ & $\begin{array}{c}-0.074^{*} \\
(0.042)\end{array}$ \\
\hline R-squared & 0.079 & 0.075 & 0.099 & 0.092 \\
\hline Root MSE & 0.07188 & 0.08163 & 0.07163 & 0.08114 \\
\hline Observations & 333 & 335 & 331 & 333 \\
\hline $\begin{array}{l}\text { Wald test on equality } \\
\text { of coefficients of } \\
\text { Volunteer_in_asso- } \\
\text { ciation and Worker }\end{array}$ & 0.453 & 0.358 & 0.322 & 0.243 \\
\hline
\end{tabular}

Note: Robust standard errors in brackets.

*Significant at 10\%; **Significant at 5\%; ***Significant at $1 \%$.

After controlling for socio-demographic variables and for the degree of involvement in the organization, we found that (Table 4):

Result 1 Volunteering in SWAs is associated with higher levels of volunteers' social capital compared with volunteering in SCs. By considering the positive and statistically significant coefficients of Volunteer_in_association reported in Table 4 (regression 1 and 2) and the sample mean of the dependent variables (Table 3), we calculate that being a volunteer in a SWA instead of a volunteer in a SC is associated with a $45 \%$ higher level of the Strong_ties 
index and with a 54\% higher level of the Weak_ties index with respect to the sample mean.

Result 2 In SCs, workers exhibit higher levels of social capital. Coefficients of Worker and dependent variable sample mean tell us that being a worker instead of a volunteer in SCs is associated with a 43\% higher value of the Strong_ties index and a 59\% higher value of the Weak_ties index, with respect to the sample mean.

Result 3 Wald tests performed on the null hypothesis that the difference between the coefficient of Volunteer_in_association and Worker is equal to zero (Table 4 - last line) inform us that there are no statistically significant differences in the two indices of Strong_ties and Weak_ties between volunteers in SWAs and workers in SCs.

Socio-demographic characteristics seem not to be significantly associated with the creation of social capital.

Table 5 sets out a robustness check conducted on the results presented in Table 4. We controlled for the following variables. At the individual level, we considered the strength of the respondent's motivation to perform her work within the organization (Current_motivation), the effort made by managers to welcome new members of the organization (Entrance) and the frequency of participation in group activities with volunteers (Contact_volunteers). At the level of the organization we took into account the total number of workers and volunteers in the organization (Workers_volunteers), the number of formal meetings held in the last 12 months (Formal_meetings), a dummy variable equal to 1 if the organization promoted informal meetings to discuss its activity (Informal_meetings) and the number of years in operation (Years_org). All the control variables were measured for both volunteers and workers, and are described in Appendix 1.

The evidence presented in Table 5 allows us to go further in investigation of both the determinants of social capital creation and the possible reasons associated with the different characteristics of the organizations and of the organizational activities performed by their members - for the different effects recorded between volunteers and workers within and between organizations.

Regressions 1 and 2 of Table 5 consider all the control variables mentioned above except for the frequency with which the respondent participated in activity groups with volunteers. These estimates confirm the higher level of social capital of volunteers in SWAs and workers in SCs with respect to that of volunteers in SCs, while Wald tests on the null hypothesis that the difference between the coefficient of Volunteer_in_association and Worker is equal to zero confirm that there are no differences in the two indices of social capital between volunteers in SWAs and workers in SCs (Table 5 - last line). Moreover, regressions 1 and 2 highlight that the Strong_ties and Weak_ties indices positively correlate with managers' efforts to support the integration of new members into the organization, for example, through group presentations, welcoming 
dinners and organized trips. They also reveal a strong association with social capital of the level of respondents' current motivation in joining the organization's activity. Finally, regression 1 reveals that the years spent in the organizations and the frequency of informal meetings to discuss organizational activity are positively associated, even though at a weak level of significance, with the Strong_ties index of social capital. The effect of informal meetings suggests that the integration of newcomers into the organization may not entirely depend on workers' individual efforts to learn how to fit in. Rather, the organization's relational climate and the human resources strategies adopted by the management are likely to play a positive role. However, the negative coefficient of the number of formal meetings held during the past year, in both regression 1 and 2 of Table 5, suggests that not all types of meeting can have the same impact on the creation of social networks. The literature on relational goods provides possible insights to explain this result. Uhlaner (1989) defined relational goods as intangible goods that cannot be enjoyed alone and that are generated as the relation with non-anonymous agents' proceeds. Examples of relational goods are friendship and social approval (Uhlaner 1989: 255). The production of relational goods is strictly based on mutual agreement (Uhlaner 1989). The creation of relational goods cannot be imposed, and goodwill is particularly important for their production. Even though they may be generated through encounters that may happen in any circumstances, some situations seem to be more convenient than others. In particular, relations that are started spontaneously are more likely to foster the creation of relational goods (Prouteau and Wolff 2004). Following these arguments, we suppose that informal meetings promoted by the organization represent more effective circumstances for the creation of social relations than formal meetings.

Finally, in regressions 3 and 4 of Table 5, we include a variable (Contact_volunteers) which measures the frequency of participation in group activities with volunteers. When this aspect is taken into account, the significance of the dummy Volunteer_in_association with respect to the Strong_ties index disappears. As commented on in the next section, this result suggests a specific role for the interaction with other volunteers in the creation of volunteers' social capital between the different types of organizations.

\section{Discussion of results}

Both workers in SCs and volunteers in the two types of organization reported that in-the-field interactions contributed to the creation of new personal contacts. If we focus on the creation of strong and weak ties by volunteers, the econometric analysis shows that SWAs perform better. If we also account for salaried workers, our results suggest that on-the-job interactions within SCs increase the individual social capital of workers to the same extent that in-thefield interactions influence the individual social capital of volunteers in SWAs. 
We find that the establishment of both weak and strong ties is significantly and positively associated with managers' efforts to support the integration of newcomers and by the degree of members' involvement in the organization's activities, measured through the current motivation of members to participate in the organization's activity.

The significance of the relationship between volunteering in SWAs and the creation of strong ties entailing mutual support disappears if we include in the analysis a control variable measuring the degree of participation in group activities with other volunteers. This result suggests that the main difference between SWAs and SCs may lie in the depth of volunteers' involvement in group activities with other volunteers. This may be related to differences in the composition of the workforce between the two types of organization. In SWAs, salaried workers constitute a great minority of the workforce. In SCs, by contrast, volunteers generally are a residual and limited part of the workforce. The effect of the degree of volunteers' involvement in group activities with other volunteers leads us to think that volunteers empathize better and develop new ties with people who have similar status and motivations, which are consistent with the claims of the literature on tokenism. The concept of tokenism (Kanter 1977) is often used to explain the effects of being a numerical minority in a relatively homogeneous environment (female tokens in male-dominated jobs in the seminal study by Kanter). Members of numerical minorities in work environments are found to receive less support from colleagues than members of the numerically dominating group (in terms, e.g. of empathy and actual assistance), to develop fewer informal ties and job-related contacts, and to report lower job satisfaction and health (Ducharme and Martin 2000; Wallace and Kay 2012).

Overall, the empirical evidence suggests that the homogeneity of members' status and motivation may be an important driver of an association's ability to foster the creation of social capital by its members.

Our results enrich the literature on associational diversity. First, we add to the debate by analysing the contribution of two specific types of Putnam groups to the creation of social capital. Second, our questionnaire allowed us to use as outcome variables refined and reliable indicators of the structural dimensions of the concept - as given by social networks of human relations with different degrees of strength. The specificity of these indicators is fundamental for providing a more in-depth evaluation of the impact of participation in non-profit organizations. In addition, our research design allowed us to exclude the existence of reverse causality - one of the most common forms of endogeneity in social capital studies - since changes that have occurred in workers' and volunteers' networks cannot in any way influence their past decision to work or volunteer for 
a SC or for a SWA. Finally, unlike previous studies on associational participation, which focus mainly on volunteers, our sample also included workers.

However, much research has to be done in the area to improve our understanding of the role of non-profit organizations - and of organizational diversity in economic development and well-being. Our results do not clarify whether the organization is able to'socialize' the sentiments of trust that are developed in the context of workers' and volunteers' personal networks. The relationship between our two main independent variables and the outcome variables accounted for in Knack and Keefer (1997) and Stolle and Rochon (1998) - i.e. civic attitudes and generalized trust - should be investigated, possibly in a larger sample.

Even if our research design allowed us to overcome reverse causality issues, other endogeneity issues still remain. Organizational participation, as workers or as volunteers, and the individual propensity of members to develop social networks as a consequence of their interaction with the organization's environment, may be influenced by omitted variables. A self-selection problem connected with the choice of joining the different types of organizations may have affected our result. ${ }^{12}$ An effort must be made to collect suitable - possibly longitudinal - data to address causality in the econometric analysis.

\section{Acknowledgments}

This work has been performed within the activity of the project "The added value of volunteer work" (in cooperation with the "Forum Solidarietà - Service Center for Voluntary Work in Parma") and "Social cooperatives and socio-economic development: an analysis starting from the concept of social capital" (in cooperation with the "Consorzio Solidarietà Sociale" - Consortium of Social Solidarity in Parma). We thank the project's participants for their fruitful cooperation. We also thank Carlo Borzaga, Marco Faillo, Lorenzo Sacconi, and Giuseppe Vittucci Marzetti for their precious feedback. The paper also benefited from comments by participants at the Conference on Public Happiness (Rome, June 4-5, 2013), at the 54th Annual Conference of the Italian Economic Association (Bologna, October 24-26, 2013), and at seminars in Moscow, Parma, Trento and Rome. Usual caveats apply.

\section{Disclosure statement}

No potential conflict of interest was reported by the authors.

\section{Notes on contributors}

Giacomo Degli Antoni is an associate professor of Economic Policy at the Department of Law of the University of Parma and Deputy Operating Director of EconomEtica - InterUniversity Center for Economic Ethics and Corporate Social Responsibility. He is member of the editorial board of the Journal of Entrepreneurial and Organizational Diversity and

\footnotetext{
${ }^{12}$ For example, one could argue that more prosocial volunteers tend to join SWAs instead of SCs. Even though we do not see a specific reason for such a possibility, our data do not allow us to exclude it categorically.
} 
of Impresa Sociale. His research interests concern: behavioural economics, social capital, non-profit organizations, ethics and economics, and corporate social responsibility.

Fabio Sabatini is an associate professor of Economic Policy at the Department of Economics and Law of Sapienza University of Rome. He collaborates with the Laboratory for Comparative Social Research (LCSR) of the Higher School of Economics (HSE) in Moscow and Saint Petersburg, and with the European Research Institute on Cooperative and Social Enterprises (Euricse) in Trento.

\section{References}

Andrews, R. (2010) “Organizational Social Capital, Structure and Performance," Human Relations 63(5): 583-608.

Antoci, A., Sabatini, F. and Sodini, M. (2012) "The Solaria Syndrome: Social Capital in a Growing Hyper-technological Economy," Journal of Economic Behavior \& Organization 81(3): 802-814.

Borzaga, C. and Defourny, J. (2001) The emergence of social enterprise, London: Routledge. Borzaga, C. and Tortia, E. (2006) "Worker Motivations, Job Satisfaction, and Loyalty in Public and Nonprofit Social Services," Nonprofit and Voluntary Sector Quarterly 35(2): 225-248.

Bourdieu, P. (1980) “Le Capital Social," Actes de la Recherche en Sciences Sociales 31: 2-3. Bourdieu, P. and Wacquant, L. (1992) An Invitation to reflexive sociology, Cambridge: Polity. Brown, T. T., Scheffler, R. M., Seo, S. and Reed, M. (2006) "The Empirical Relationship between Community Social Capital and the Demand for Cigarettes," Health Economics 15: $1159-1172$.

Coleman, J. S. (1990) Foundations of Social Theory, Cambridge: Harvard University Press.

Degli Antoni, G. (2009) “Intrinsic vs. Extrinsic Motivations to Volunteer and Social Capital Formation," Kyklos 62(3): 359-370.

Degli Antoni, G. and Portale, E. (2011) "The Effect of Corporate Social Responsibility on Social Capital Creation in Social Cooperatives," Nonprofit and Voluntary Sector Quarterly 40(3): 566-582.

Ducharme, L. J. and Martin, J. K. (2000) “Unrewarding Work, Coworker Support, and Job Satisfaction," Work \& Occupations 27: 223-243.

European Commission (2005) The Contribution of Social Capital in the Social Economy to Local Economic Development in Western Europe. EU Research in Social Sciences and Humanities. Final Report. Brussels: European Commission.

Findlay, P., Kalleberg, A. L. and Warhurst, C. (2013) "The Challenge of Job Quality," Human Relations 66(4): 441-451.

Fiorillo, D. and Sabatini, F. (2011) "Quality and Quantity: The Role of Social Interactions in Self-reported Individual Health," Social Science and Medicine 73: 1644-1652.

Folland, S. (2006) "Value of Life and Behavior Toward Health Risks: An Interpretation of Social Capital," Health Economics 15(2): 159-171.

Granovetter, M. (1973) “The Strength of Weak Ties," American Journal of Sociology 78(6): 1360-1380.

Grießhaber, N. and Geys, B. (2012) "Civic Engagement and Corruption in 20 European Democracies," European Societies 14(1): 57-81.

Grootaert, C. and Van Bastelaer, T. (Eds) (2001) The Role of Social Capital in Development: An Empirical Assessment, Cambridge: Cambridge University Press.

Gui, B. (2000) "Beyond Transactions: On the Interpersonal Dimension of Economic Reality," Annals of Public and Cooperative Economics 71(2): 139-169. 
Hansen, M. T. (1999) "The Search-transfer Problem: The Role of Weak Ties in Sharing Knowledge across Organization Subunits," Administrative Science Quarterly 44(1): 82-111.

Haski-Leventhal, D. and Bargal, D. (2008) "The Volunteer Stages and Transitions Model: Organizational Socialization of Volunteers," Human Relations 61(1): 67-102.

Hooghe, M. (1998) "Voluntary Associations and Democratic Attitudes: Value Congruence as a Causal Mechanism," in M. Hooghe and D. Stolle (eds.) Generating Social Capital. Civil Society and Institutions in Comparative Perspective, 89-111. New York, NY: Palgrave MacMillan.

Huck, S., Kübler, D. and Weibull, J. (2012) "Social Norms and Economic Incentives in Firms," Journal of Economic Behavior \& Organization 83(2): 173-185.

Istat (2003) Le Organizzazioni di Volontariato in Italia [Voluntary organizations in Italy], Rome: Istat.

Kandel, E. and Lazear, E. P. (1992) "Peer Pressure and Partnerships," Journal of Political Economy 100(4): 801-817.

Kanter, R. M. (1977) "Some effects of proportions on group life: Skewed sex ratios and responses to token women," American journal of Sociology 965-990.

Kerlin, J. A. (2006) "Social Enterprise in the United States and Europe: Understanding and Learning from the Differences," Voluntas: International Journal of Voluntary and Nonprofit Organizations 17(3): 247-263.

Kerlin, J. A. (2010) "A Comparative Analysis of the Global Emergence of Social Enterprise," Voluntas: International Journal of Voluntary and Nonprofit Organizations 21(2):162-179.

Knack, S. and Keefer, P. (1997) "Does Social Capital Have an Economic Payoff?" The Quarterly Journal of Economics 112(4): 1251-1288.

Leana, C. R. and Van Buren, H. J. (1999) “Organizational Social Capital and Employment Practices," Academy of Management Review 24: 538-555.

March, J. G., and Simon, H. A. (1958) Organizations, New York, NY: Wiley.

Mäkelä, K. and Brewster, C. (2009) "Interunit Interaction Contexts, Interpersonal Social Capital, and the Differing Levels of Knowledge Sharing," Human Resource Management 48(4): 591-613.

Nahapiet, J. and Ghoshal, S. (1998) "Social Capital, Intellectual Capital, and the Organizational Advantage," Academy of Management Review 23(2): 242-266.

OECD (2010) Social Capital, Human Capital and Health: What is the Evidence? Paris: OECD.

Paldam, M. (2000) "Social Capital: One or Many? Definition and Measurament," Journal of Economic Surveys. 14(5): 629-653.

Prouteau, L. and Wolff, F.-C. (2004) "Relational Goods and Associational Participation," Annals of Public \& Cooperative Economics 75(3): 431-463.

Putnam, R. D. (1995) "Bowling Alone: America's Declining Social Capital," Journal of Democracy VI: 65-78.

Putnam, R. D. (2000) Bowling Alone. The Collapse and Revival of American Community. New York, NY: Simon \& Schuster.

Putnam, R. D., Leonardi, R. and Nanetti, R. Y. (1993) Making Democracy Work, Princeton, NJ: Princeton University Press.

Robison, L. J., Schmid, A. A. and Siles, M. E. (2002) "Is Social Capital Really Capital?" Review of Social Economy 60(1): 1-21.

Sabatini, F. (2008) “Does Social Capital Improve Labour Productivity in Small and Medium Enterprises?" International Journal of Management and Decision Making 9(5): 454-480.

Sabatini, F., Modena, F. and Tortia, E. (2014) "Do Cooperative Enterprises Create Social Trust?" Small Business Economics 42(3): 621-641.

Schuller, T. (2007) "Reflections on the Use of Social Capital," Review of Social Economy 65(1): 11-28. 
Stolle, D. and Rochon, T. R. (1998) "Are All Associations Alike?" American Behavioral Scientist 42(1): 47-65.

Uhlaner, C. J. (1989) "Relational Goods and Participation: Incorporating Sociability into a Theory of Rational Action," Public Choice 62(3): 253-285.

Uphoff, N. (1999) "Understanding Social Capital: Learning from the Analysis and Experience of Participation," in P. Dasgupta and I. Serageldin (eds.) Social Capital: A Multifaceted Perspective, 215-249, Washington, DC: The World Bank.

Wallace, J. A. and Kay, F. M. (2012) “Tokenism, Organizational Segregation, and Coworker Relations in Law Firms," Social Problems 59(3): 389-410.

World Bank (2011) "Social Capital and Civil Society." Available at: http://go.worldbank. org/4NQ143KXT0

Zhang, Y. and Lin, N. (2016) "Hiring for Networks: Social Capital and Staffing Practices in Transitional China," Human Resource Management55 (4): 615-635.

\section{Appendix 1. Description variables}

\begin{tabular}{|c|c|}
\hline \multicolumn{2}{|l|}{ Individual variables } \\
\hline $\begin{array}{l}\text { Volunteer_in_ } \\
\text { association }\end{array}$ & Dummy variable $(D V)=1$ if volunteer in a SWA \\
\hline Worker & $\mathrm{DV}=1$ if worker in a SC \\
\hline Age & Respondent's age in years \\
\hline Female & $\mathrm{DV}=1$ respondent is a female \\
\hline University & $\mathrm{DV}=1$ respondent has at least a university degree \\
\hline Time_in_org & Years spent in the organization \\
\hline Current_motivation & $\begin{array}{l}\text { Strength of the current respondent's motivation to engage in the organization's } \\
\text { activities, between } 1 \text { (I feel really poorly motivated in my work) and } 7 \text { (very } \\
\text { strongly motivated) }\end{array}$ \\
\hline Entrance & $\begin{array}{l}\text { Effort made by managers to welcome new members of the organization (e.g. } \\
\text { group presentations, social dinners) }\end{array}$ \\
\hline Contact_volunteers & $\begin{array}{l}\text { How often, from } 1 \text { (never) to } 5 \text { (every week), the respondent participates in } \\
\text { group activities with volunteers }\end{array}$ \\
\hline \multicolumn{2}{|c|}{ Organizational variables } \\
\hline Years_org & Number of years in operation \\
\hline Workers_volunteers & Total number of workers and volunteers in the organization \\
\hline Formal_meetings & Number of formal meetings held in the last 12 months \\
\hline Informal_meetings & DV $=1$ if the organization promotes informal meetings to discuss its activity \\
\hline
\end{tabular}

